\title{
Cell mediated immunity in relation to cataract and cataract surgery
}

\author{
C. J. J. BRINKMAN AND R. M. BROEKHUYSE \\ From the Institute of Ophthalmology, University of Nijmegen, Nijmegen, The Netherlands
}

SUMMARY Two groups of patients suffering from cataract were investigated by the lymphocyte stimulation test. One group was tested before and the other after cataract surgery. Human (total) lens crystallins and bovine alpha crystallin were used as the antigens. Lymphocytes of healthy persons showed practically no positive stimulation with either antigen. Of the patients tested before operation $38 \%$ reacted positively with lens crystallins and $15 \%$ with alpha crystallin. This difference in sensitisation suggests a leakage of lenticular antigens other than alpha crystallin out of the lens during cataract progression. Extracapsular lens extraction caused an increase in the number of patients reacting positively with lens crystallins and alpha crystallin as compared to patients not operated upon. Intracapsular lens extraction on the other hand resulted in less sensitisation to lens crystallins as compared to patients not operated upon.

The isolation of the lens proteins from the fetal circulation early in embryonic life, the lack of innervation, and the complete avascularity of the adult lens might suggest that the lens proteins initiate an autologous sensitisation after entering the aqueous humour. However, it has only recently been possible to detect antibodies to homologous lens proteins in small amounts in rabbits (Misra et al., 1977). Earlier attempts to stimulate antilens antibody formation were successful only by sensitisation with homologous lens proteins in combination with an adjuvant (Halbert et al., 1965). The presence of an adjuvant still seems necessary for the immune response to autologous lens antigens (Rahi et al., 1977).

Phacogenic uveitis or lens-induced uveitis, which is characterised by a sterile iridocyclitis, is thought to be the result of autosensitisation to lens proteins. Clinically this inflammation may develop within 2 days after perforation of the lens capsule (Schlaegel, 1975), indicating a secondary immune response. The primary response of the immune system could have been evoked by leakage of lenticular antigen into the aqueous humour during cataract maturation. Because it is difficult to induce a good antibody response after immunisation with homologous or autologous lens proteins it is likely that cellular

Address for reprints: Dr C. J. J. Brinkman, Institute of Ophthalmology, University of Nijmegen, Philips van Leydenlaan 15, Nijmegen, The Netherlands immunity plays a role in the induction of phacogenic uveitis.

The present study deals with the in-vitro stimulation by lens crystallins and alpha crystallin of lymphocytes of patients suffering from cataract in order to investigate this possible leakage. In addition, a comparison of lymphocyte activation has been made before and after cataract surgery.

\section{Patients and methods}

The investigation covered 49 patients suffering from cataract, who were divided into 2 groups. The first group consisted of 21 patients who were tested 1 day before cataract surgery and who had not been operated on before. The second group consisted of 28 patients who were tested at least 18 days after cataract surgery. Patients who received corticosteroid or other anti-inflammatory preparations during the investigation were excluded. Twenty-two healthy volunteers (age range 20 to 64 years, including 8 persons between 51 and 64 years) served as controls. Two of them could not be tested with alpha crystallin.

\section{PREPARATION OF ANTIGENS}

Cataractous lenses (age range of patients 60 to 70 years) removed after intracapsular lens extraction were used after storage at $-70^{\circ} \mathrm{C}$. Lens crystallins were isolated by homogenisation of the decapsulated lenses in excess $0.01 \mathrm{M}$ ammonium acetate buffer $\left(\mathrm{pH} \mathrm{7.2)}\right.$ in a Potter-Elvehjem tube at $4^{\circ} \mathrm{C}$. The 
suspension was centrifuged for 1 hour at $15000 \mathrm{~g}$ at $4^{\circ} \mathrm{C}$ and the supernatant was lyophilised and stored at $-20^{\circ} \mathrm{C}$ until used. Protein content of the dry weight material (lens crystallins) was determined by the Lowry method (Lowry et al., 1951) and amounted to $80 \%$. Serum albumin was used as standard.

Alpha crystallin, the non-species-specific lens crystallin (Halbert et al., 1965), was isolated from fresh decapsulated bovine lenses as follows. Bovine lens crystallins were isolated as from human lenses; $80 \mathrm{mg}$ of bovine lens crystallins were dissolved in $5 \mathrm{ml} 0.1 \mathrm{M}$ ammonium acetate buffer $(\mathrm{pH} \mathrm{8.0)}$ supplemented with $0.5 \%$ butanol and applied to a Sepharose 6B column $(100 \times 2.5 \mathrm{~mm})$ (Bours and Brahma, 1973). The column was eluted with the same buffer. The fractions containing pure alpha crystallin (as checked by isoelectrofocusing) (Bours and Brahma, 1973) were lyophilised and stored at $-20^{\circ} \mathrm{C}$ until used.

LYMPHOCYTE STIMULATION ASSAY (LSA)

Heparinised blood was diluted with an equal volume of Eagle's minimum essential medium (MEM). The mononuclear cells were isolated from the diluted blood by Ficoll-Isopaque centrifugation (Du Bois et al., 1973). Lymphocytes, $3 \times 10^{5}$, were suspended in $1 \mathrm{ml}$ MEM supplemented with 100 units of penicillin and $0.1 \mathrm{mg}$ of streptomycin per millilitre and $20 \%$ heat-inactivated A-rh positive serum. Cultures of lymphocytes were incubated in triplicate with $1 \mathrm{mg}$ human lens crystallins or $50 \mu \mathrm{g}$ bovine alpha crystallin for 6 to 7 days. Viability and stimulation activity was checked by incubating the lymphocytes with $5 \mu \mathrm{g}$ phytohaemagglutinin-P (Difco) for 3 days. Control cultures contained neither antigen nor mitogen. Sterility was controlled by incubating the antigens alone in the culture medium. Twenty-four hours before harvesting, $0.5 \mu \mathrm{Ci}$ tritiated thymidine (specific activity 25 curi/millimole) was added. Harvesting of the cells was done by filtration under reduced pressure through Millipore glassfibre filters. The filters were incubated in $0.5-\mathrm{ml}$ Nuclear Chicago Solubilizer (NCS), diluted 1 to 3 with toluene-based scintillation fluid containing $100 \mathrm{mg}$ dimethyl-POPOP* and $5 \mathrm{~g}$ $\mathrm{PPO}+/$ litre for 30 minutes at $20^{\circ} \mathrm{C}$. After addition of $9.5 \mathrm{ml}$ scintillation fluid containing $1 \mathrm{ml}$ glacial acetic acid per litre the activity was determined in a liquid scintillation counter. The degree of stimulation was expressed as the stimulation index (SI). SI = counts per minute $(\mathrm{cpm})$ in the presence of antigen divided by $\mathrm{cpm}$ in the absence of antigen. An SI $\geqslant 3$ with human lens crystallins and an

*POPOP $=$ 2,2-p-phenylen bis (5-phenyloxazol). $\dagger \mathrm{PPO}=2,5$-diphenyloxazol.
SI $\geqslant 2$ with bovine alpha crystallin was considered to be positive.

\section{Results}

LSA BEFORE CATARACT SURGERY

Lymphocytes from 21 patients, obtained 1 day before cataract surgery, were cultured with total lens crystallins and alpha crystallin. Eight $(38 \%)$ of these patients showed a positive lymphocyte response with total lens crystallins (Table 1, Fig. 1). Two healthy persons $(9 \%)$ showed a positive lymphocyte stimulation with lens crystallins (persons aged 34 and 64 years) (Fig. 1). The difference in total lens crystallins sensitisation between healthy persons and cataract patients was statistically significant $(P<0.05$; Fisher's one-sided exact test $)$. Alpha crystallin produced a positive lymphocyte culture in $3(15 \%)$ of the 20 patients investigated (Table 1, Fig. 1), which was statistically insignificant in comparison with the group of 20 healthy persons, who did not react with alpha crystallin $(P>0 \cdot 1)$ (Fig. 1). In addition to 5 patients with a mature cataract 14 patients suffered from a cataract in which the lens cortex was involved, and 8 patients

Table 1 Stimulation of lymphocytes of patients, suffering from cataract, before cataract surgery

\begin{tabular}{|c|c|c|c|c|c|c|c|}
\hline \multirow[b]{2}{*}{ Case } & \multirow[b]{2}{*}{ Sex } & \multirow[b]{2}{*}{$\begin{array}{l}\text { Age } \\
(y r)\end{array}$} & \multicolumn{3}{|c|}{ Cataract type } & \multicolumn{2}{|c|}{ Stimulation index with } \\
\hline & & & Nuclear & Cortical & Other & $\begin{array}{l}\text { Lens } \\
\text { crystallins* }\end{array}$ & $\begin{array}{l}\text { Alpha } \\
\text { crystallin† }\end{array}$ \\
\hline 1 & $\mathbf{M}$ & 77 & & + & & - & - \\
\hline 2 & $\mathbf{M}$ & 58 & & & Mature & - & - \\
\hline 3 & $\mathbf{M}$ & 63 & + & + & & - & - \\
\hline 4 & $\mathbf{F}$ & 39 & & & Mature & - & - \\
\hline 5 & $\mathbf{M}$ & 38 & & + & & + & + \\
\hline 6 & $\mathbf{M}$ & 42 & & + & & - & - \\
\hline 7 & $\mathbf{F}$ & 78 & + & + & & - & - \\
\hline 8 & $\mathbf{M}$ & 75 & & + & & - & - \\
\hline 9 & $\mathbf{M}$ & 57 & & & Mature & ++ & - \\
\hline 10 & $\mathbf{M}$ & 66 & & + & & ++ & - \\
\hline 11 & $\mathbf{M}$ & 66 & + & & & - & - \\
\hline 12 & $\mathbf{F}$ & 71 & + & + & & ++ & - \\
\hline 13 & $\mathbf{M}$ & 64 & + & + & & - & - \\
\hline 14 & $\mathbf{M}$ & 53 & & + & & - & - \\
\hline 15 & $\mathbf{M}$ & 64 & & & Mature & $++t$ & ++ \\
\hline 16 & $\mathbf{F}$ & 71 & & & Mature & ++ & - \\
\hline 17 & $\mathbf{F}$ & 76 & + & + & & - & - \\
\hline 18 & $\mathbf{M}$ & 57 & & + & & $+t+$ & + \\
\hline 19 & $\mathbf{M}$ & 79 & + & + & & $++t$ & - \\
\hline 20 & $\mathbf{M}$ & 67 & & + & & - & - \\
\hline 21 & $\mathbf{F}$ & 83 & + & & & - & ND \\
\hline
\end{tabular}




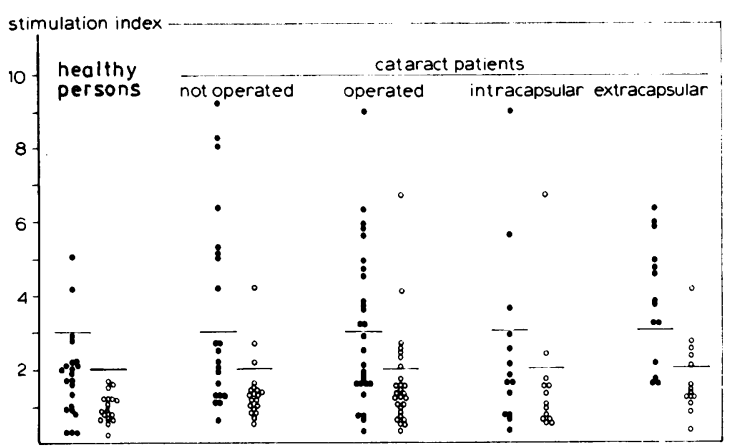

Fig. 1 Stimulation of lymphocytes of healthy persons and cataract patients by total human lens crystallins (O) and bovine alpha crystallin $(\mathrm{O})$. The influence of cataract surgery and type of lens extraction (intracapsular and extracapsular) are shown. An $S I \geqslant 3$ with total human lens crystallins and an $S I \geqslant 2$ with bovine alpha crystallin (horizontal bars) was considered to be positive

Table 2 Stimulation of lymphocytes of patients after cataract surgery

\begin{tabular}{|c|c|c|c|c|c|c|}
\hline \multirow[b]{2}{*}{ Case } & \multirow[b]{2}{*}{ Sex } & \multirow[b]{2}{*}{$\begin{array}{l}\text { Age } \\
(y r)\end{array}$} & \multicolumn{2}{|c|}{ Stimulation index with } & \multicolumn{2}{|c|}{ Lens extraction } \\
\hline & & & $\begin{array}{l}\text { Lens } \\
\text { crystallins* }\end{array}$ & $\begin{array}{l}\text { Alpha } \\
\text { crystallin } \dagger\end{array}$ & $\begin{array}{l}\text { Intra- } \\
\text { capsular }\end{array}$ & $\begin{array}{l}\text { Extra- } \\
\text { capsular }\end{array}$ \\
\hline 22 & $\mathbf{F}$ & 69 & - & - & + & \\
\hline 23 & $\mathbf{M}$ & 28 & + & + & & + \\
\hline 24 & $\mathbf{M}$ & 39 & + & - & & + \\
\hline 25 & $\mathbf{F}$ & 69 & - & - & + & \\
\hline 26 & $\mathbf{M}$ & 58 & - & - & + & \\
\hline 27 & $\mathbf{F}$ & 63 & - & - & & + \\
\hline 28 & $\mathbf{M}$ & 78 & - & - & + & \\
\hline 29 & $\mathbf{M}$ & 77 & - & - & & + \\
\hline 30 & $\mathbf{F}$ & 60 & - & - & & + \\
\hline 31 & $\mathbf{M}$ & 71 & + & - & & + \\
\hline 32 & $\mathbf{F}$ & 66 & - & - & + & \\
\hline 33 & $\mathbf{F}$ & 65 & + & - & & + \\
\hline 34 & $\mathbf{M}$ & 73 & + & - & & + \\
\hline 35 & $\mathbf{F}$ & 86 & - & - & + & \\
\hline 36 & $\mathbf{F}$ & 65 & ++ & + & & + \\
\hline 37 & $\mathbf{M}$ & 42 & ++ & + & & + \\
\hline 38 & $\mathbf{M}$ & 67 & - & - & + & \\
\hline 39 & $\mathbf{M}$ & 66 & + & ++ & & + \\
\hline 40 & $\mathbf{F}$ & 78 & ++ & $+t+$ & + & \\
\hline 41 & $\mathbf{F}$ & 80 & + & + & + & \\
\hline 42 & $\mathbf{F}$ & 71 & - & - & & + \\
\hline 43 & $\mathbf{M}$ & 66 & + & - & & + \\
\hline 44 & $\mathbf{M}$ & 62 & ++ & + & & + \\
\hline 45 & $\mathbf{M}$ & 64 & - & - & + & \\
\hline 46 & $\mathbf{M}$ & 82 & - & - & + & \\
\hline 47 & $\mathbf{F}$ & 83 & - & - & + & \\
\hline 48 & $\mathbf{F}$ & 71 & $++t$ & ND $\ddagger$ & + & \\
\hline 49 & $\mathbf{M}$ & 57 & - & - & + & \\
\hline
\end{tabular}

$+=$ SI 3-5; $++=$ SI 5-7; $\quad+++=$ SI $>7$.

$++=$ SI 2-4; $++=$ SI 4-6; $+++=$ SI $>6$.

$\ddagger$ Not determined. suffered from a cataract in which the lens nucleus was involved.

\section{LSA AFTER CATARACT SURGERY}

A positive stimulation index with total lens crystallins was found in $13(46 \%)$ of the 28 patients who underwent cataract surgery (Table 2, Fig. 1), which is about the same percentage as before cataract surgery. Lens extraction produced a rise in the number of patients who reacted positively with alpha crystallin (Table 2, Fig. 1). Seven patients $(26 \%)$ of the 27 were alpha crystallin sensitive after operation, which was significantly higher than in the group of healthy persons $(P<0.05)$.

Table 2 and Fig. 1 also show the influence of the type of cataract extraction on the sensitisation to total lens crystallins and alpha crystallin. Of 14 patients who underwent intracapsular lens extraction 3 patients $(21 \%)$ reacted positively with lens crystallins and $2(15 \%)$ of the 13 tested patients reacted positively with alpha crystallin. These numbers were not significantly different from those of healthy persons $(\mathrm{P}>0 \cdot 1$ for both antigen fractions). However, of 14 patients who underwent extracapsular lens extraction $10(71 \%)$ showed sensitisation to lens crystallins and $5(35 \%)$ to alpha crystallin. This difference in alpha crystallin and lens crystallins sensitisation between patients who underwent extracapsular lens extraction and healthy persons was statistically significant $(P<0.01$ and $P<0.0005$, respectively).

\section{Discussion}

Differences have been found in protein content as well as in protein composition between normal and cataractous lenses. Declining lens transparency appears to be associated with a decrease in the quantity of soluble lens proteins and an increase in the amount of insoluble proteins (Mach, 1963). A preferential decrease in low molecular weight proteins during progressive cataract formation was found by Sephadex gel filtration (François et al., 1965). Several authors suggested that these proteins are gamma crystallin (Maisel and Goodman, 1965; Croft, 1973). According to Harding and Dilley (1976) different explanations are possible for this decline in low molecular weight proteins in the lens, namely, by leakage through the lens capsule, by conversion into insoluble proteins, by cross-linking, or by a lack of synthesis. Mach (1963) has already demonstrated that the increase in protein insolubilisation cannot account for the decrease in quantity of soluble low molecular weight lens proteins during cataractogenesis. Charlton and van Heyningen (1968) considered the possibility of leakage of low 
molecular weight proteins out of the lens, but their results did not lead to definite conclusions.

If leakage of lenticular proteins does occur during opacification of the lens, an immune response could be provoked leading to a population of sensitised lymphocytes in the patients' blood. The present investigation supports this by showing that about $38 \%$ of the cataract patients (who had not been operated on before) had lymphocytes which could be stimulated by lens crystallins (Table 1). Normal persons showed practically no positive reactions with lens crystallins. Only $3(15 \%)$ of the 20 patients investigated reacted positively with alpha crystallin (Table 1). One of these 3 patients suffered from a mature cataract and another patient suffered besides from cataract from recurrent uveitis. None of the control persons showed a positive response to alpha crystallin. As is shown in Table 1 , most $(66 \%)$ of the patients who had not been operated on before suffered from a cortical cataract in contrast to $38 \%$ of these patients with a nuclear cataract.

Philipson (1973) compared the morphological changes in both cortical and nuclear cataractous lenses by electron microscopy, microradiography, and light scattering. The cortical opacities appeared to be accompanied by an enlargement of intercellular spaces followed by lens membrane damage. The human nuclear cataract looked completely different. In this type of cataract lens fibre cells and membranes did not show any difference from those of normal lenses. The morphological changes commonly seen in cortical cataractous lenses may lead to selective permeability of the lens capsule, resulting in liberation of low molecular weight lens proteins, subsequently provoking an immunological response. The high percentage of patients with cortical cataract, present in the group of patients who had not been operated on before, strengthens the idea that leakage of the lenticular proteins depends on the condition of the lens cortex rather than the lens nucleus.

Cataract surgery seems to have little influence on the sensitisation of the lymphocytes to total lens crystallins. On the contrary, after cataract surgery an increase in the number of patients sensitive to alpha crystallin could be detected.

Separating the patients according to the type of cataract extraction showed that after extracapsular lens extraction $71 \%$ of the patients reacted positively with lens crystallins and $35 \%$ with alpha crystallin. Of patients who underwent intracapsular lens extraction, however, $21 \%$ showed a sensitisation to lens crystallins and $15 \%$ to alpha crystallin. This difference in sensitisation to lens crystallins and to alpha crystallin between both types of extraction procedures can be explained by the liberation of lens antigens into the aqueous humour, which is accomplished during extracapsular lens extraction. Intracapsular lens extraction results in a complete removal of the source of lens antigens. The latter also explains the lower percentage of patients showing sensitivity to lens crystallins after intracapsular lens extraction as compared to the patients not operated on.

The results suggest that lenticular proteins other than alpha crystallin are free to pass the lens capsule predominantly in cortical cataractous lenses. After entering the aqueous humour a primary immune response can be induced leading to a population of sensitised lymphocytes. This primary sensitisation possibly concerns a cell mediated response because: (a) Attempts to induce anti-lens antibodies were successful only in the presence of an adjuvant (Halbert et al., 1965); (b) low molecular weight lens proteins tend to aggregate and precipitate after leakage from the lens (Charlton and van Heyningen, 1968), a phenomenon which favours T-cell activation (Manski, 1973).

Phacogenic uveitis is a sterile inflammation and is supposed to be the result of an immunological reaction to lens remnants present in the aqueous humour, especially after extracapsular lens extraction. This type of uveitis develops sometimes very soon (1 or 2 days) after lens extraction (Schlaegel, 1975), which made us conclude that we are dealing with a secondary immune response, primary sensitisation being evoked by low molecular weight lens crystallins.

We thank Mrs Maria Oerlemans-van Zutphen for her skilful technical assistance.

\section{References}

Bours, J., and Brahma, S. K. (1973). Isoelectric focusing of embryonic cow lens crystallins. Experimental Eye Research, 16, 131-142.

Charlton, J. M., and van Heyningen, R. (1968). An investigation into the loss of proteins of low molecular size from the lens in senile cataract. Experimental Eye Research, 7, 47-55.

Croft, L. R. (1973). Low molecular weight proteins of the lens. In The Human Lens, Ciba Symposium No. 19 (new series), pp. 207-226. Excerpta Medica: Amsterdam.

Du Bois, M. J. G. J., Huismans, D. R., Schellekens, P. Th. A., and Eysvogel, V. P. (1973). Investigation and standardization of the conditions of microlymphocyte cultures. Tissue Antigens, 3, 402-409.

François, J., Rabaey, M., and Stockmans, L. (1965). Gel filtration of the soluble proteins from normal and cataractous human lenses. Experimental Eye Research, 4, 312-318.

Halbert, S. P., Manski, W., and Ehrlich, G. (1965). Autoimmunization in the eye. Annals of the New York Academy of Sciences, 124, 332-351.

Harding, J. J., and Dilley, K. J. (1976). Structural proteins of the mammalian lens: A review with emphasis on changes in development, aging and cataract. Experimental Eye Research, 22, 1-73. 
Lowry, O. H., Rosebrough, N. J., Farr, A. L., and Randall, R. J. (1951). Protein measurement with the folin phenol reagent. Journal of Biological Chemistry, 193, 265-275.

Mach, H. (1963). Untersuchungen von Linseneiweiss und Microelectrophorese von wasserlöslichem Eiweiss im Altersstar. Klinische Monatsblätter für Augenheilkunde, 143, 689-710.

Maisel, H., and Goodman, M. (1965). The ontogeny and specificity of human lens proteins. Investigative Ophthalmology, 4, 129-137.

Manski, W. (1973). Immunological studies on normal and pathological lenses. In The Human Lens, Ciba Symposium No. 19 (new series), pp. 227-248. Excerpta Medica: Amsterdam.

Misra, R. N., Rahi, A. H. S., and Morgan, G. (1977).
Immunopathology of the lens. II. Humoral and cellular immune responses to homologous lens antigens and their roles in ocular inflammation. British Journal of Ophthalmology, 61, 285-296.

Philipson, B. (1973). Changes in the lens related to the reduction of transparency. Experimental Eye Research, 16, 29-39.

Rahi, A. H. S., Misra, R. N., and Morgan, G. (1977). Immunopathology of the lens. III. Humoral and cellular immune responses to autologous lens antigens and their roles in ocular inflammation. British Journal of Ophthalmology, 61, 371-379.

Schlaegel, T. F. (1975). Uveitis following cataract surgery. In Cataract and Abnormalities of the Lens, p. 429. Edited by J. G. Belows. Grune \& Stratton: New York. 